\title{
Respons Mahasiswa Fakultas Pertanian Universitas Gadjah Mada terhadap Aplikasi Desa Apps
}

\author{
Students of Faculty of Agriculture in Universitas Gadjah Mada Response Towards Desa Apps \\ Application
}

\author{
Adrian Apritas Djitmau, Alia Bihrajihant Raya, Harsoyo dan Galuh Friska Cahyani
}

Program Studi Penyuluhan dan Komunikasi Pertanian.

Departemen Sosial Ekonomi Pertanian, Fakultas Pertanian

Universitas Gadjah Mada

Email: alia.bihrajihant.r@ugm.ac.id

\begin{abstract}
Applications on smartphones are functions that are made to facilitate human activities. Nowadays, many applications are used as sources of information, including in agriculture. One application that is a source of agricultural information is Desa Apps. Research on the response of UGM Faculty of Agriculture students to the Desa Apps Application was made with the aim of knowing: 1) Students of Faculty of Agriculture UGM responses towards Desa Apps Applications, 2) Factors that affect students of Faculty of Agriculture UGM responses towards Desa Apps Applications. The method used in this research is descriptive analysis method. Sampling of respondent students was done by simple random sampling. The total sample is 60 students, 12 students from each department. The analytical method used is the proportion test and multiple linear regression analysis with the Backward method. The results of the study show that most students have a good response to the Desa Apps Application. Student motivation has a positive effect, the quality of information has a positive effect, and the completeness of features has a positive effect. The significance value of the motivation factor is 0.073 with a regression coefficient of 0.168 , the significance value of the information quality factor is 0.003 , with the regression coefficient of 0.353 , the significance value of the feature completeness factor is 0.044 with the regression coefficient of 0.191.
\end{abstract}

Keywords: Application, Information, Agriculture, Desa Apps, Response.

\begin{abstract}
Abstrak: Aplikasi pada smartphone adalah suatu fungsi yang dibuat untuk memudahkan kegiatan manusia. Saat ini aplikasi banyak dijadikan sumber informasi tidak terkecuali dalam bidang pertanian. Salah satu aplikasi yang menjadi sumber informasi pertanian adalah Desa Apps. Penelitian mengenai respons mahasiswa Fakultas Pertanian UGM terhadap Aplikasi Desa Apps ini dibuat dengan tujuan untuk mengetahui: 1) Respons mahasiswa Fakultas Pertanian UGM terhadap Aplikasi Desa Apps, 2) Faktor-faktor yang mempengaruhi respons mahasiswa Fakultas Pertanian UGM terhadap Aplikasi Desa Apps. Metode yang digunakan dalam penelitian ini adalah metode analisis deskriptif. Pengambilan sampel mahasiswa responden dilakukan dengan acak sederhana (simple random sampling). Total sampel berjumlah 60 mahasiswa yaitu 12 mahasiswa dari masing-masing departemen. Metode analisis yang digunakan adalah uji proporsi dan analisis regresi linier berganda dengan metode Backward. Hasil penelitian menunjukkan bahwa sebagian besar mahasiswa memiliki respons yang baik terhadap Aplikasi Desa Apps. Motivasi mahasiswa berpengaruh positif, kualitas informasi berpengaruh positif, dan kelengkapan fitur berpengaruh positif. Nilai signifikansi faktor motivasi 0,073 dengan nilai koefisien regresi 0,168 , nilai signifikansi faktor kualitas informasi 0,003 , dengan nilai koefisien regresi 0,353 , nilai signifikansi faktor kelengkapan fitur 0,044 dengan nilai koefisien regresi 0,191 .
\end{abstract}

Kata Kunci: Aplikasi, Informasi, Pertanian, Desa Apps, Respons. 


\section{PENDAHULUAN}

Indonesia adalah salah satu negara berkembang dengan jumlah populasi manusia yang cukup besar. Perkembangan teknologi pada era globalisasi yang sangatlah pesat turut berdampak kepada gaya hidup yang dianut oleh masyarakat Indonesia. Penggunaan ponsel pintar atau smartphone sudah menjadi hal yang biasa ditemui dalam kehidupan sehari-hari. Ponsel pintar sudah menjadi salah satu kebutuhan utama bagi setiap kalangan dari setiap generasi. Menurut Kementrian Riset Teknologi dan Pendidikan Tinggi Indonesia (2017) pada akhir tahun 2016 pengguna smartphone di Indonesia adalah 25\% dari total penduduk Indonesia atau sekitar 65 juta orang dan diperkirakan bisa mencapai 100 juta pengguna.

Perkembangan teknologi informasi menghasilkan suatu terobosan baru yaitu sistem operasi berbasis Android. Sistem operasi android memberikan banyak kemudahan kepada masyarakat. Dengan kemunculan android para penggiat di bidang teknologi informasi turut terpacu untuk menciptakan berbagai aplikasi yang bisa bermanfaat bagi masyarakat. Menurut Nazarudin (2012), android diartikan sebagai sistem operasi untuk telepon seluler yang berbasis Linux. Android menyediakan platform terbuka bagi para pengembang untuk menciptakan aplikasi mereka sendiri untuk digunakan oleh bermacam peranti bergerak.

Kemunculan aplikasi dirasa mampu membuat masyarakat semakin dipermudah dalam memenuhi kebutuhan hidupnya. Berdasarkan kebutuhan hidupnya manusia memiliki tiga kebutuhan utama yaitu Existence, Relatedness, dan Growth. Menurut Maslow dalam Kirei (2017) Existence atau keberadaan adalah suatu kebutuhan akan tetap bisa hidup sesuai dengan tingkat kebutuhan tingkat rendah dari Maslow yaitu meliputi kebutuhan fisiologis dan kebutuhan akan rasa aman. Relatedness atau hubungan mencakup kebutuhan untuk berinteraksi dengan orang lain. Kebutuhan ini sesuai dengan kebutuhan afiliasi dari Maslow. Sedangkan Growth atau pertumbuhan adalah kebutuhan yang mendorong seseorang untuk memiliki pengaruh yang kreatif dan produktif terhadap diri sendiri atau lingkungan. Realisasi dari kebutuhan penghargaan dan perwujudan diri dari Maslow.
Aplikasi berbasis android yang dikembangkan bisa bergerak dalam berbagai sektor dan tidak terbatas dalam satu bidang saja. Salah satu bidang yang sedang digencarkan untuk merambah ke arah modernisasi ini adalah bidang pertanian. Di dunia pertanian peran informasi sangat dibutuhkan agar terciptanya sinergi antara perkembangan ilmu dan pengetahuan para petani serta pelaku pertanian lainnya sehingga dapat menghasilkan produk dengan kualitas baik dan meningkatkan daya jual produk tersebut (Pebriana, 2017). Dengan adanya penggunaan berbagai macam aplikasi yang bisa menunjang penyebaran informasi pertanian kepada petani maka proses penyuluhan akan menjadi semakin dipermudah dan bisa menyebar secara merata dan meluas.

Salah satu aplikasi pertanian yang sedang dikembangkan sebagai sarana penyuluhan pertanian di Indonesia adalah "Desa Apps". Desa Apps adalah aplikasi yang membantu para petani pintar dalam proses penanaman, perawatan, panen, penjualan, dan penyedia informasi. Aplikasi Desa Apps dikembangkan oleh Gamatechno yaitu perusahaan yang bergerak di bidang penyedia solusi teknologi informasi. Desa Apps adalah aplikasi milik Universitas Gadjah Mada (UGM) Yogyakarta yang bekerjasama dengan Fakultas Pertanian UGM. Desa Apps diluncurkan secara resmi pada tahun 2016.

Mahasiswa pertanian adalah salah satu calon pelaku pertanian di masa yang akan datang dan diharapkan bisa menjadi agent of change menuju ke arah yang lebih baik. Menurut Rikardo (2018) mahasiswa sebagai agen dari suatu perubahan memiliki arti bahwa mahasiswa diharapkan bisa memberikan suatu kebermanfaatan dengan pandangan-pandangan baru agar suatu yang salah berubah menjadi benar dan lebih baik. Dengan harapan bahwa suatu hari mahasiswa dapat menggunakan disiplin ilmunya dalam membantu pembangunan Indonesia untuk menjadi lebih baik kedepannya. Mahasiswa adalah salah satu harapan suatu bangsa agar bisa berubah ke arah lebih baik. hal ini dikarenakan mahasiswa dianggap memiliki intelek yang cukup bagus dan cara berpikir yang lebih matang, sehingga diharapkan mereka dapat menjadi jembatan antara rakyat dengan pemerintah.

Mengetahui respons Mahasiswa Fakultas Pertanian UGM terhadap Aplikasi Desa Apps adalah hal yang sangat penting untuk dilakukan 
dimana aplikasi pertanian Desa Apps sendiri merupakan suatu aplikasi yang dikembangkan oleh UGM sebagai sarana penyuluhan pertanian. Respons sendiri bisa diartikan sebagai suatu sikap yang merupakan reaksi reaksi atas aksi terhadap diri. Respons merupakan sikap, dan sikap terdiri dari afeksi (perasaan), kognisi (pengetahuan), dan konasi (perilaku atau partisipasi). Pengetahuan seseorang adalah wawasan yang dimiliki seseorang yang dapat memberikan pemahaman terhadap masalah yang dihadapi. Pengetahuan seseorang akan mempengaruhi sikap dan perilaku seseorang orang tersebut dalam menanggapi rangsangan dari luar. Semakin luas pengetahuan seseorang, maka akan semakin berkembang ilmunya dan berani untuk mencoba inovasi baru (Wirawan, 1995).

Dalam penelitian ini ada berbagai macam faktor yang diduga mempengaruhi respons yang bisa berasal dari dalam maupun luar dari individu mahasiswa. Adapun beberapa diantaranya adalah jenis kelamin, departemen, aksesibilitas, motivasi, kualitas informasi, kelengkapan fitur, kemudahan aplikasi, dan juga desain aplikasi. Menurut Gill (1986) dalam Sukadiyanto (2004) perbedaan jenis kelamin menunjukkan empat area kemampuan yaitu kemampuan verbal, matematika, visualspatial (kecerdasan yang berkaitan dengan kemampuan seseorang untuk menangkap dunia ruang visual secara akurat dan mampu melakukan perubahan-perubahan terhadap persepsinya tersebut), dan agresifitas. Pada laki-laki lebih memiliki kemampuan matematika, visual-spatial, dan agresifitas, sedangkan pada perempuan lebih memiliki kemampuan verbal yang baik. Pada penelitian ini pengaruh jenis kelamin diukur dari perbandingan jumlah mahasiswa laki-laki dengan mahasiswa perempuan yang memiliki respons baik terhadap Aplikasi Desa Apps.

Departemen adalah Pada perguruan tinggi terdapat penjurusan (departemen) bagi mahasiswa berdasarkan subyek mata kuliah yang diambil. Setiap departemen memiliki materi dan sifat pembelajaran yang berbeda. Departemen yang memiliki sifat yang serupa akan digabung dalam suatu fakultas, akademi, sekolah tinggi, dan lain sebagainya. Pada dasarnya setiap orang yang ingin melanjutkan di perguruan tinggi akan memilih jurusan sesuai yang di inginkan dan diharapkan jurusan yang sesuai dapat membekali setiap mahasiswa menghadapi tantangan masa depan (Risnawati dan Irwandi, 2012). Menurut Laranti
(2017) Departemen atau jurusan menentukan bidang ilmu apa yang dipelajari oleh mahasiswa dan menjadi konsentrasi studi mahasiswa tersebut, sehingga menunjukkan kecenderungan dan minat dari mahasiswa tersebut untuk mendapatkan informasi tertentu. Pada penelitian ini departemen yang ada di Fakultas Pertanian UGM dibagi dalam dua kategori yaitu kategori HPT dan non-HPT (Sosial Ekonomi Pertanian Budidaya Pertanian, Tanah, dan Mikrobiologi Pertanian). Pengaruh departemen diukur dengan membandingankan jumlah respons baik mahasiswa HPT dan nonHPT.

Ekonomi Pertanian Budidaya Pertanian, Tanah, dan Mikrobiologi Pertanian). Pengaruh departemen diukur dengan membandingankan jumlah respons baik mahasiswa HPT dan nonHPT.

Aksesibilitas adalah suatu ukuran kenyamanan atau kemudahan lokasi tata guna lahan dalam berinteraksi satu sama lain, dan mudah atau sulitnya lokasi tersebut dicapai melalui transportasi (Black,1981). Pendapat lain, aksesibilitas adalah ukuran kemudahan yang meliputi waktu, biaya, dan usaha dalam melakukan perpindahan antara tempat-tempat atau kawasan dari sebuah sistem (Magribi, 1999). Semakin aksesibilitas tinggi maka respons yang dihasilkan juga akan semakin tinggi. Semakin media tersebut mudah dijangkau, maka kemungkinan para penggunanya untuk mengakses tentu akan semakin tinggi.

Istilah motivasi berasal dari kata motif yang dapat diartikan sebagai kekuatan yang terdapat dalam diri individu, yang menyebabkan individu tersebut bertindak atau berbuat. Motif tidak dapat diamati secara langsung, tetapi dapat diinterpretasikan dalam tingkah lakunya, berupa rangsangan, dorongan, atau pembangkit tenaga munculnya suatu tingkah laku tertentu (Uno, 2013). Motivasi adalah dorongan dasar yang menggerakkan seseorang bertingkah laku. Dorongan ini berada pada diri seseorang yang menggerakkan untuk melakukan sesuatu yang sesuai dengan dengan dorongan dalam dirinya. Oleh karena itu, perbuatan seseorang yang didasarkan atas motivasi tertentu mengandung tema sesuai dengan motivasi yang mendasarinya.

Motivasi juga dapat dikatakan sebagai perbedaan antara dapat melaksanakan dan mau melaksanakan. Motivasi lebih dekat pada mau melaksanankan tugas untuk mencapai tujuan. 
Motivasi adalah kekuatan, baik dari dalam maupun dari luar yang mendorong seseorang untuk mencapai tujuan tertentu yang telah ditetapkan sebelumnya. Atau dengan kata lain, motivasi dapat diartikan sebagai dorongan mental terhadap perorangan atau orang-orang sebagai anggota masyarakat. Motivasi dapat juga diartikan sebagai proses untuk mencoba memengaruhi orang atau orang-orang yang dipimpinnnya agar melakukan pekerjaan yang diinginkan, sesuai dengan tujuan tertentu yang ditetapkan lebih dahulu (Uno, 2013). Motivasi penggunaan bisa mempengaruhi respons seseorang terhadap penggunaan aplikasi pertanian ini dikarenakan semakin seseorang termotivasi untuk menggunakan tentu saja respons yang ditimbulkan adalah tinggi.

Ada berbagai macam teori motivasi. Pada penelitian ini akan difokuskan pada teori "ERG" yang dikembangkan oleh Clayton Alderfer dari Universitas Yale. "ERG" merupakan akronim dari Existense, Relatedness, dan Growth. Menurut teori tersebut eksistensi adalah kebutuhan paling dasar bagi manusia. Setiap orang ingin mempertahankan eksistensinya secara terhormat termasuk kebutuhan primer dan keamanan. Relatedness tercermin dari sifat dasar manusia sebagai makhluk sosial yang membutuhkan hubungan dengan individu lain. Growth menunjukkan kebutuhan seseorang untuk bertumbuh dan berkembang misalnya dalam peningkatan ketrampilan pada pekerjaannya untuk memperoleh kemajuan (Siagian, 1995).

Kualitas informasi bisa diartikan sebagai mutu atau tingkat baik atau buruknya suatu nfromasi yang diberikan oleh Desa Apps. Hal ini diperkuat dengan pernyataan Deming yang menyatakan bahwa kualitas sebagai kesesuaian dengan kebutuhan pasar atau konsumen (1982). Informasi yang berkualitas menunjukkan bahwa informasi yang disajikan sesuai dengan apa yang menjadi kebutuhan user atau pengguna dari aplikasi berdasarkan dimensi kualitas informasi. Menurut O'Brien (2006), tiga dimensi kualitas informasi yaitu meliputi dimensi waktu informasi (time dimension), dimensi konten informasi (content dimension), dan dimensi bentuk informasi (form dimension). Time Dimension (dimensi waktu informasi) artinya adalah informasi dikatakan berkualitas jika memenuhi pesan yang up to date. Content Dimension (dimensi konten informasi) artinya bahwa informasi memiliki nilai akurasi yang tepat, dan tingkat relevansi yang tinggi. Sedangkan Form Dimension (dimensi bentuk informasi), yaitu apabila bentuk informasi adalah cara bagaimana informasi tersebut sampai ke user. Suatu sistem dari penggunaan IT harus dapat menyediakan informasi untuk mendukung pengambilan keputusan. Oleh karena itu semua itu tergantung pada kualitas informasi yang dihasilkan seperti yang diungkapkan O'Briens (2005) dalam Septianita (2014).

Kelengkapan fitur adalah perancangan fitur suatu aplikasi sebaiknya sederhana sehingga mudah digunakan. Agar dapat dimanfaatkan pada berbagai kegiatan fitur yang tersedia pada aplikasi harus cukup lengkap. Fitur yang lengkap pada aplikasi dapat mempengaruhi respons orang terhadap aplikasi tersebut. Pengaruh kelengkapan informasi dilihat dari sisi agribisnis untuk menunjang kegiatan pertanian seperti input, proses, pemasaran (Putri, dkk, 2005).

Menurut Muntianah dkk (2012), penggunaan suatu teknologi dapat menunjang dan memperlancar kegiatan pengguna, jika suatu teknologi bermanfaat dan mudah dioperasikan maka akan semakin sering digunakan. Teknologi yang digunakan dapat mempengaruhi sikap pengguna, hal ini berkaitan dengan respons pengguna terhadap aplikasi tersebut. Kemudahan aplikasi secara garis besar bisa diartikan sebagai kemudahan aplikasi Desa Apps dioperasikan oleh para user.

Desain aplikasi adalah rancangan tampilan aplikasi yang dapat dilihat oleh penggunanya. Desain antarmuka aplikasi yang baik dimulai dengan desain minimalis yaitu desain yang efektif tanpa perlu menambah hal-hal yang tidak begitu penting, kemudian struktur tata letak dalam aplikasi yang enak dipandang, sebaiknya pelajari juga desain yang saat ini sedang trend, kemudian 20 tipografi yang sesuai seperti jenis, ukuran, dan warna tulisan, jangan lupakan whitespace yaitu area kosong yang memberi ruang bagi pengguna aplikasi untuk fokus pada area tertentu dan tidak membingungkan pengguna aplikasi (Japrie, 2012). Pengaruh desain Aplikasi Desa Apps dilihat dari tulisan, tata letak konten, dan warna antarmuka aplikasi.

Berkaitan dengan respons Mahasiswa Fakultas Pertanian UGM terhadap Aplikasi Desa Apps perlu adanya kajian mengenai faktor-faktor 
yang mempengaruhi respons Mahasiswa terhadap Aplikasi Desa Apps. Penelitian ini memiliki nilai kebaruan dalam dua pendekatan yaitu 1) pendekatan teoritis, hasil penelitian ini dapat memberikan kontribusi pada pengembangan teori komunikasi massa khususnya pada penggunaan media baru berbasis internet oleh mahasiswa pertanian dan pelaku pertanian dan

2) pendekatan praktis, hasil penelitian ini dapat memberikan kontribusi pada aplikasiaplikasi pertanian dalam pengembangan aplikasi tersebut.

\section{METODE PENELITIAN}

Penelitian ini dilakukan di Fakultas Pertanian Universitas Gadjah Mada, Yogyakarta. Responden diambil dari Mahasiswa Fakultas Pertanian UGM sebanyak 60 orang yang terbagi kedalam 5 Departemen yaitu Departemen Hama dan Penyakit Tumbuhan, Departemen Sosial Ekonomi Pertanian, Departemen Budidaya Pertanian, Departemen Ilmu Tanah, dan Departemen Mikrobiologi Pertanian. Pengambilan responden dilakukan dengan metode Simple random sampling. Metode Simple random sampling adalah suatu bentuk teknik pengambilan sampel dengan cara mengacak nama. Pengambilan nama responden dilakukan dengan bantuan aplikasi Microsoft excel, sehingga akan didapatkan sejumlah nama responden dengan secara acak. Dari masing-masing departemen diambil dari tiga angkatan tahun masuk yaitu angkatan 2017, 2016, dan 2015. Pengambilan data dilakukan pada rentang waktu September 2018 -Oktober 2018 dengan menggunakan kuesioner yang dibuat secara online dan metode wawancara. Pengujian yang dilakukan pada penelitian ini adalah uji proporsi untuk mengetahui respons mahasiswa menggunakan rumus:
Z hitung =

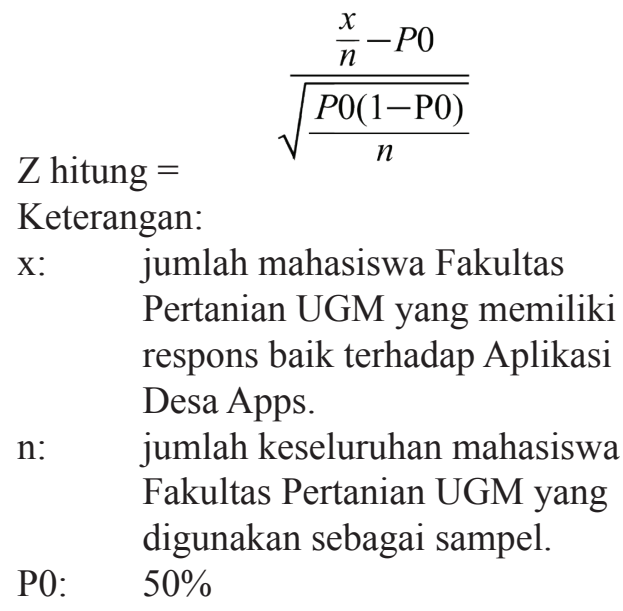

Pengujian selanjutnya adalah analisis regresi linear berganda menggunakan software SPSS 16.0 dengan persamaan:

\begin{tabular}{|c|c|}
\hline \multicolumn{2}{|c|}{ Keterangan: } \\
\hline $\mathrm{Y}$ & : Respons \\
\hline $\mathrm{B}$ & : Koefisien Regresi \\
\hline $\mathrm{X} 1$ & : Dummy Jenis Kelamin \\
\hline $\mathrm{X} 2$ & : Dummy Departemen \\
\hline $\mathrm{X} 3$ & : Aksesibilitas \\
\hline $\mathrm{X} 4$ & : Motivasi \\
\hline $\mathrm{X} 5$ & : Kualitas Informasi \\
\hline $\mathrm{X} 6$ & : Kelengkapan Fitur \\
\hline $\mathrm{X} 7$ & : Kemudahan Aplikasi \\
\hline $\mathrm{X} 8$ & : Desain Aplikasi \\
\hline
\end{tabular}

\section{HASIL DAN PEMBAHASAN}

\section{Respons Mahasiswa Fakultas Pertaniaan UGM Terhadap Aplikasi Desa Apps}

Pada penelitian ini terdapat beberapa indikator respons Mahasiswa Fakultas Pertanian UGM terhadap Aplikasi Desa Apps yang dapat dilihat pada tabel berikut. 
Tabel 1. Tingkat Respons Mahasiswa Fakultas Pertanian UGM Terhadap Aplikasi Desa Apps

\begin{tabular}{|c|c|c|c|c|}
\hline No. & Indikator & $\begin{array}{l}\text { Interval } \\
\text { Skor }\end{array}$ & $\begin{array}{l}\text { Rerata } \\
\text { Capaian }\end{array}$ & $\begin{array}{c}\text { Tingkat } \\
\text { Respons }(\%)\end{array}$ \\
\hline 1 & $\begin{array}{l}\text { Aplikasi Desa Apps dapat membantu kegiatan pertanian } \\
\text { di Indonesia }\end{array}$ & $0-5$ & 3,97 & 79,33 \\
\hline 2 & Aplikasi Desa Apps dapat digunakan setiap waktu & $0-5$ & 3,95 & 79,00 \\
\hline 3 & Aplikasi Desa Apps dapat digunakan di berbagai tempat & $0-4$ & 2,60 & 65,00 \\
\hline 4 & $\begin{array}{l}\text { Fitur-fitur yang tersedia pada Aplikasi Desa Apps } \\
\text { bermanfaat }\end{array}$ & $0-5$ & 4,22 & 84,33 \\
\hline 5 & $\begin{array}{l}\text { Aplikasi Desa Apps dapat menyebarkan informasi } \\
\text { dalam waktu singkat }\end{array}$ & $0-5$ & 3,98 & 79,67 \\
\hline 6 & $\begin{array}{l}\text { Ada biaya yang diperlukan dalam mengakses Aplikasi } \\
\text { Desa Apps }\end{array}$ & $0-5$ & 4,07 & 81,33 \\
\hline 7 & $\begin{array}{l}\text { Aplikasi Desa Apps sebagai sarana untuk mencari } \\
\text { informasi pertanian }\end{array}$ & $0-5$ & 4,18 & 83,67 \\
\hline 8 & $\begin{array}{l}\text { Kredibilitas informasi yang ada pada Aplikasi Desa } \\
\text { Apps }\end{array}$ & $0-5$ & 4,00 & 80,00 \\
\hline 9 & Kualitas artikel yang ada pada Aplikasi Desa Apps & $0-5$ & 4,15 & 83,00 \\
\hline \multirow[t]{3}{*}{10} & Artikel yang tersedia di Aplikasi Desa Apps beragam & $0-6$ & 3,87 & 64,44 \\
\hline & Jumlah & $0-50$ & 38,98 & \\
\hline & Rerata & & & 77,98 \\
\hline
\end{tabular}

Sumber: Analisis Data Primer, 2019.

Berdasarkan Tabel 1 dapat dilihat bahwa rata-rata Mahasiswa Fakultas Pertanian UGM memiliki respons dengan persentase sebesar $77,98 \%$. Hal tersebut menunjukkan bahwa Mahasiswa Fakultas Pertanian UGM memiliki respons yang baik terhadap Aplikasi Desa Apps. Mahasiswa mengetahui dan menganggap fiturfitur yang tersedia pada Aplikasi Desa Apps bermanfaat karena cukup lengkap dan bermanfaat seperti fitur tanya jawab, artikel, info cuaca, info toko, info kantor, dan catatan tani, hal tersebut terbukti dengan indikator ini memiliki persentase paling tinggi yaitu $84,33 \%$. Indikator terendah respons Mahasiswa Fakultas Pertanian UGM terhadap Aplikasi Desa Apps adalah keragaman

artikel yang tersedia di Aplikasi Desa Apps dengan persentase $64,44 \%$, hal ini berarti jumlah artikel yang tersedia di Aplikasi Desa Apps belum cukup beragam bagi pengguna, hal ini dapat ditingkatkan dengan melibatkan mahasiswa untuk menulis atau mengunggah artikel pada Aplikasi Desa Apps. Rerata persentase dari seluruh indikator respons yang ada menunjukkan bahwa Mahasiswa Fakultas Pertanian UGM memiliki respons yang baik terhadap Aplikasi Desa Apps. Skor indikator respons pada penelitian ini dibagi menjadi tiga yaitu rendah, sedang, dan tinggi. Sebaran skor indikator respons pada penelitian ini dapat dilihat pada tabel 2 berikut.

Tabel 2 Sebaran Skor Indikator Respons Mahasiswa Fakultas Pertanian UGM Terhadap Aplikasi Desa Apps

\begin{tabular}{llccr}
\hline No. & Tingkatan Indikator & $\begin{array}{c}\text { Interval } \\
\text { Skor }\end{array}$ & Jumlah (Jiwa) & Persentase (\%) \\
\hline 1 & Rendah & $0-16,67$ & 0 & 0,00 \\
2 & Sedang & $16,68-33,34$ & 2 & 3.33 \\
3 & Tinggi & $33,35-50$ & 58 & 96.67 \\
\hline & Jumlah & & 60 & 100.00 \\
\hline
\end{tabular}

Sumber: Analisis Data Primer, 2019 
Untuk membuktikan respons Mahasiswa Fakultas Pertanian UGM terhadap Aplikasi Desa Apps dapat digunakan rumus berikut.

$$
\text { Zhitung }=\frac{\frac{x}{n}-P 0}{\sqrt{\frac{P 0(1-\mathrm{P} 0)}{n}}} \text { Zhitung }=\frac{\frac{58}{60}-0,5}{\sqrt{\frac{0,5(1-0,5)}{60}}} \text { Zhitung }=7,297
$$

Pada pengujian proporsi di atas didapat hasil perhitungan $Z$ hitung sebesar 7,297. Nilai $\mathrm{Z}$ hitung yang didapat lebih besar dari nilai $\mathrm{Z}$ tabel yaitu sebesar 1,282 pada $\alpha=10 \%$. Hal ini berarti Mahasiswa Fakultas Pertanian Universitas Gadjah Mada memiliki respons baik (mendukung) terhadap Aplikasi Desa Apps.

Pada penelitian ini terdapat beberapa faktor yang diduga mempengaruhi respons Mahasiswa Fakultas Pertanian UGM terhadap Aplikasi Desa Apps. Faktor-faktor yang diduga mempengaruhi respons mahasiswa tersebut dikelompokkan menjadi dua yaitu faktor internal dan faktor eksternal. Faktor internal yang diduga mempengaruhi respons Mahasiswa Fakultas Pertanian UGM yaitu jenis kelamin, departemen, aksesibilitas, dan motivasi. Faktor eksternal yang diduga mempengaruhi respons Mahasiswa

Fakultas Pertanian Universitas Gadjah Mada adalah kualitas informasi, kelengkapan fitur, kemudahan aplikasi, dan desain aplikasi.

\section{Faktor-faktor Yang Mempengaruhi Respons Mahasiswa Fakultas Pertanian UGM Terhadap Aplikasi Desa Apps}

Pengaruh dari faktor atau varibel dianalisa menggunakan software SPSS 16.0 dengan metode backward dan taraf signifikansi $\alpha=10 \%$. Variabel yang mempengaruhi disebut variabel independent (dilambangkan dengan $\mathrm{X}$ ), sedangkan variabelyang dipengaruhi disebut dependent (dilambangkan dengan Y). Setelah dilakukan pengujian regresi linear berganda dengan menggunakan metode backward menghasilkan 6 model regresi dan yang akan ditampilkan adalah model 1 (pertama) dan model 6 (akhir). Hasil analisis tersebut akan disajikan pada Tabel 3 berikut.

Tabel 3 Hasil Analisis Linear Berganda Mengenai Faktor-Faktor yang Mempengaruhi Respons Mahasiswa UGM Terhadap Aplikasi Desa Apps (Model 1 Backward)

\begin{tabular}{lcrrr}
\hline Variabel & Koefisien Regresi (B) & t hit. & Sig. & Ket. \\
\hline Jenis Kelamin(X1) & 0,049 & 0,511 & 0,612 & NS \\
Departemen (X2) & 0,000 & 0,004 & 0,997 & NS \\
Aksesibilitas (X3) & 0,107 & 1,045 & 0,301 & NS \\
Motivasi (X4) & 0,158 & 1,586 & 0,119 & NS \\
Kualitas Informasi (X5) & 0,347 & 2,650 & 0,011 & $*$ \\
Kelengkapan Fitur (X6) & 0,200 & 1,893 & 0,064 & $*$ \\
Kemudahan Aplikasi (X7) & 0,015 & 0,113 & 0,910 & NS \\
Desain Aplikasi (X8) & $-0,074$ & $-0,595$ & 0,554 & NS \\
\hline Konstanta & 1,031 & & & \\
R Square & 0,484 & & & \\
Adjusted R Square & 0,403 & & & \\
F Hitung & 5,977 & & & \\
F Tabel & 1,794 & & & \\
Keterangan: & & & & \\
*: Signifikan pada $\alpha=10 \%$ & & & & \\
NS: Not Significant atau tidak signifikan pada $\alpha=10 \%$ & & & & \\
\hline
\end{tabular}

Sumber: Analisis Data Primer, 2019 
Pada Tabel 3 dapat dilihat hasil regresi linear berganda model 1 faktor-faktor yang mempengaruhi respons mahasiswa. Pada regresi linear berganda model 1 tersebut semua variabel ditampilkan baik yang berpengaruh nyata maupun yang tidak berpengaruh nyata terhadap respons mahasiswa. Model 1 menunjukkan terdapat 2 variabel yang berpengaruh nyata pada respons Mahasiswa Fakultas Pertanian UGM terhadap

Tabel 4. Hasil Analisis Linear Berganda Mengenai Faktor-Faktor yang Mempengaruhi Respons Mahasiswa UGM Terhadap Aplikasi Desa Apps (Model 6 Backward)

\begin{tabular}{llcrrr}
\hline No & Variabel & Koefisien Regresi (B) & t hit. & Sig. & Ket. \\
\hline 1 & Motivasi (X4) & 0,168 & 1,828 & 0,073 & $*$ \\
2 & Kualitas Informasi (X5) & 0,353 & 3,151 & 0,003 & $*$ \\
3 & Kelengkapan Fitur (X6) & 0,191 & 2,064 & 0,044 & $*$ \\
\hline \multirow{2}{*}{ Konstanta } & 1,174 & & & \\
& R Square & 0,461 & & & \\
& Adjusted R Square & 0,432 & & & \\
& F Hitung & 15,935 & & & \\
& F Tabel & 2,184 & & & \\
& Keterangan: & & & & \\
& *: Signifikan pada $\alpha=10 \%$ & & & & \\
\hline
\end{tabular}

Sumber: Analisis Data Primer, 2019

Pada Tabel 4 hasil analisis regresi linear berganda dengan metode backward menunjukkan model 6 atau model akhir dari analisis tersebut. Metode backward pada analisis regresi linear berganda menyeleksi variabel-variabel independen yang ada hingga tersisa variabel yang berpengaruh nyata. Pada model 6 ini terdapat 3 variabel independen yang berpengaruh nyata pada respons Mahasiswa Fakultas Pertanian UGM terhadap Aplikasi Desa Apps, yaitu variabel motivasi (X4), kualitas informasi (X5), dan kelengkapan fitur (X6). Motivasi berpengaruh nyata pada respons mahasiswa terhadap aplikasi Desa Apps yang dihasilkan, apabila kita menijau pada hasil sebaran diketahui bahwa motivasi mahasiwa berada pada kategori tinggi. Hal tersebut memperlihatkan bahwa para mahasiswa di Fakultas pertanian UGM memiliki keinginan untuk menggunakan aplikasi tersebut terutama untuk memenuhi kebutuhan pada aspek growth atau berkembang. Hal ini sesuai dengan penelitian dari Zakaria dan Rahman(2018) dalam penelitiannya yang bertajuk Pengaruh Motivasi Dan Penggunaan Internet Terhadap
Aplikasi Desa Apps, yaitu variabel kualitas informasi (X5) dan kelengkapan fitur (X6) pada Aplikasi Desa Apps, sedangkan terdapat 6 variabel yang tidak berpengaruh nyata pada taraf signifikansi $10 \%$ ini, yaitu jenis kelamin (X1), departemen (X2), aksesibilitas (X3), motivasi (X4), kemudahan aplikasi (X7), dan desain aplikasi (X8). 
internet sebagai sumber pustaka. Sebagai sesorang yang dianggap berpendidikan tinggi, mahasiswa dituntut untuk mampu melakukan sortasi terhadap infromasi yang diterimanya. Mahasiswa harus bisa membedakan informasi yang terbilang kredibel atau tidak, selain itu mahasiswa juga harus memperhatikan nilai proximity dari infromasi yang ia cari, apakah sudah relevan dengan apa yang ia butuhkan atau tidak. Penelitian lain yang dilakukan oleh Pratama (2013), menunjukan bahwa kualitas infromasi memang berpengaruh secara nyata dan positif terhadap penggunaan internet sebagai sumber pustaka mahasiwa.

Faktor terakhir yang berpengaruh adalah kelengkapan fitur. itur produkmenurut Armstrong dan Kotler dalam Hamidah dan Anita (2013), yaitu alat persaingan untukmembedakan produk perusahaan terhadap produk sejenis yang menjadipesaingnya. Dengan berbagai fitur produk yang ditawarkan oleh produsen,konsumen akan semakin terpuaskan dengan produk-produk yang sesuai dengan kebutuhannya guna mendiferensiasi produk yang dihasilkan oleh perusahaan terhadap produk sejenis yang dihasilkan perusahaan lain diperlukan suatu alatyang dapat menjadi nilai tambah bagi konsumen untuk dapat memilih produk tersebut, alat tersebut salah satunya dengan menggunakan fituryang ada dalam produk tersebut. Dalam penelitiannya, hamidah dan Anita juga menemukan bahwa kelengkapan fitur berpengaruh terhadap kepeutusan pembelian Handphone yang menandakan bahwa berkaitan dengan respons pembeli. Hal ini sesuai dengan hasil penelitian yang menunjukan bahwa kelengkapan fitur berpengaruh nyata terhadap respons mahasiswa yang terbentuk.

Dari tabel 4 dapat dilihat bahwa nilai $\mathrm{R}$ square adalah 0,461 . Nilai $\mathrm{R}$ square menunjukkan ketepatan dari fungsi regresi tersebut. Semakin mendekati nilai 1 , maka fungsi dari regresi akan semakin tepat. Nilai adjusted $\mathrm{R}$ square yang dihasilkan dari pengujian analisis linear berganda pada penelitian ini adalah 0,432 . Hal ini berarti 43,2\% respons Mahasiswa Fakultas Pertanian UGM dipengaruhi oleh variabel motivasi, kualitas informasi, dan kelengkapan fitur, sedangkan 56,8\% respons mahasiswa dipengaruhi oleh variabel lainnya. Pada penelitian ini juga dihasilkan nilai $\mathrm{F}$ hitung sebesar 15,935 dan nilai $\mathrm{F}$ tabel sebesar 2,184 . Nilai $F$ menunjukkan pengaruh dari variabel independen secara bersama-sama atau serempak terhadap variabel dependen. Nilai $\mathrm{F}$ hitung yang dihasilkan lebih besar dari nilai $\mathrm{F}$ tabel, hal ini berarti variabel independen (motivasi, kualitas informasi, dan kelengkapan fitur) secara bersamasama berpengaruh nyata terhadap variabel dependen (respons). Variabel yang berpengaruh nyata pada respons Mahasiswa Fakultas Pertanian UGM terhadap Aplikasi Desa Apps menunjukkan hasil berikut.

Pada tabel 4 nilai koefisien regresi variabel motivasi (X4) sebesar 0,168 dan nilai signifikansi 0,073 . Nilai signifikansi variabel motivasi lebih kecil dari nilai alpha $10 \%$ atau 0,1 , sehingga hipotesis motivasi berpengaruh pada respons Mahasiswa Fakultas Pertanian UGM terhadap Aplikasi Desa Apps diterima. Nilai koefisien Regresi sebesar 0,168 menunjukkan bahwa motivasi berpengaruh nyata secara positif (+) pada respons Mahasiswa Fakultas Pertanian UGM terhadap Aplikasi Desa Apps. Hal ini berarti jika motivasi mahasiswa tinggi maka respons mahasiswa terhadap Aplikasi Desa Apps akan tinggi, sedangkan jika motivasi mahasiswa rendah maka respons mahasiswa terhadap Aplikasi Desa Apps juga menurun.

Variabel kualitas informasi (X5) memiliki nilai koefisien regresi sebesar 0,353 dan nilai signifikansi sebesar 0,003. Nilai signifikansi variabel kualitas informasi lebih kecil dari nilai alpha $10 \%$ atau 0,1 sehingga hipotesis kualitas informasi berpengaruh terhadap respons mahasiswa diterima. Nilai koefisien regresi sebesar 0,353 pada variabel kualitas informasi menunjukkan pengaruh nyata secara positif $(+)$, artinya jika kualitas informasi pada Aplikasi Desa Apps baik maka respons mahasiswa terhadap aplikasi tersebut akan baik, sebaliknya jika kualitas informasi pada Aplikasi Desa Apps kurang bagus maka respons mahasiswa terhadap aplikasi tersebut akan menurun juga.

Variabel kelengkapan fitur (X6) memiliki nilai koefisien regresi sebesar 0,191 dan nilai signifikansi sebesar 0,044 pada tabel 6.4. Nilai signifikansi variabel kelengkapan fitur sebesar 0,044 lebih kecil dibanding nilai alpha sebesar $10 \%$, sehingga hipotesis kelengkapan fitur berpengaruh terhadap respons mahasiswa diterima. Nilai koefisien regresi sebesar 0,191 menunjukkan variabel kelengkapan fitur berpengaruh nyata secara positif $(+)$. Hal ini berarti semakin lengkap fitur pada Aplikasi Desa Apps maka respons 
mahasiswa akan semakin baik terhadap aplikasi tersebut, sebalikya jika fitur pada Aplikasi Desa Apps kurang lengkap maka respons mahasiswa terhadap aplikasi tersebut akan berkurang (menurun) juga.

Secara keseluruhan respons Mahasiswa Fakultas Pertanian UGM dapat dikatakan tinggi. Peningkatan respons mahasiswa Fakultas Pertanian UGM tergantung pada motivasi dalam menggunakan Aplikasi Desa Apps, kualitas informasi yang disajikan, dan kelengkapan fitur pada aplikasi tersebut. Oleh karena itu pengelola Aplikasi Desa Apps perlu memperhatikan hal-hal seperti pengoptimalan Aplikasi Desa Apps pada kegiatan belajar-mengajar, promosi Aplikasi Desa Apps, memperbanyak artikel yang aktual dan beragam, perbaikan akurasai link, dan memberikan akses kepada mahasiswa untuk bisa mengunggah artikel pada Aplikasi Desa Apps.

\section{KESIMPULAN DAN SARAN}

Sebagian besar Mahasiswa Fakultas Pertanian Universitas Gadjah Mada memiliki respons yang baik (mendukung) terhadap Aplikasi Desa Apps. Motivasi Mahasiswa Fakultas Pertanian UGM terhadap Aplikasi Desa Apps tergolong tinggi, semakin tinggi motivasi mahasiswa maka respons mahasiswa terhadap Aplikasi Desa Apps akan semakin tinggi. Hal yang perlu ditingkatkan pada motivasi mahasiswa adalah kepekaan sebagai mahasiswa fakultas pertanian terhadap kondisi pertanian sekitar dengan memanfaatkan berbagai media termasuk Aplikasi Desa Apps, pengoptimalan Aplikasi Desa Apps pada kegiatan belajar mengajar di Fakultas Pertanian UGM, dan promosi Aplikasi Desa Apps memanfaatkan poster, leaflet, sosial media, atau website Fakultas Pertanian.

Kualitas informasi pada Aplikasi Desa Apps tergolong baik, semakin baik kualitas informasi pada Aplikasi Desa Apps maka respons Mahasiswa Fakultas Pertanian UGM terhadap Aplikasi Desa Apps akan semakin baik. Hal yang perlu ditingkatkan pada kualitas informasi Aplikasi Desa Apps adalah memuat lebih banyak artikel dan memuat artikel yang sedang hangat dibicarakan, bisa dengan menggandeng mahasiswa sebagai penyuplai artikel.
Fitur pada Aplikasi Desa Apps dapat dikatakan lengkap, semakin lengkap fitur pada Aplikasi Desa Apps maka respons Mahasiswa Fakultas Pertanian UGM terhadap Aplikasi Desa Apps akan semakin baik. Hal yang perlu ditingkatkan pada kelengkapan fitur Aplikasi Desa Apps adalah memperbaiki keakuratan link pada artikel yang dimuat.

\section{UCAPAN TERIMA KASIH}

Penelitian ini didanai oleh Hibah Fakultas Pertanian UGM Tahun 2017. Terima kasih kepada Dr. Ir. Roso Witjaksono, M.S. yang telah memberikan masukan dalam penelitian ini.

\section{DAFTAR PUSTAKA}

Afiatin, T. 1993. Persepsi pria dan wanita terhadap kemandirian. Jurnal Psikologi, Vol 1 (1) : 7-13.

Amin, M., Sugiyanto, Sukesi, K., dan Ismadi. 2013. Application of cyber extension as communication media to empower the dry land farmer at Donggala District, Central Sulawesi. Journal of Basic and Applied Scientific Research, Vol. 3 (4) : 379-385.

Anggraeni dan Irviani. 2017. Pengantar Sistem Informasi. Penerbit Andi, Yogyakarta.

Elian, N., Lubis, D. J., dan Rangkuti, P. A. 2014. Penggunaan internet dan pemanfaatan informasi pertanian oleh penyuluh pertanian di Kabupaten Bogor wilayah barat. Jurnal Komunikasi Pembangunan, Vol. 12 (2) : 104-109. Black, J.A. (1981). Urban transport planning: theory and practice. London. Cromm Helm.

Deming, W.E.(1982). Out of the CrisisQuality,Productivity,and competitive Position.Cambridge University Press

Elliot, S.(1993).Management of Quality in Computing System Education: ISO 9000 Series Quality Standards Applied. Journal of System Management, September,6-11 dan 41-42. 
Hamidah, Siti., Anita, Desi. 2013.Analisis Persepsi Citra Merek, Desain, Fitur, dan Pengaruhnya terhadap Keputusan Pembelian Produk Handphone Samsung Berbasis Android (Studi Kasus Stie Pelita Indonesia). Jurnal Ekonomi. Vol.21:1-20.

Kirei, Febrina Calysta. Teori Kebutuhan "ERG". https://www.dictio.id/t/apa-yang-dimaksuddengan-teori-alderfer-s-existencerelatedness-ang-growth-erg/12765. Diakses pada tanggal 23 Agustus 2019

Kementerian Komunikasi dan Informastika Republik Indonesia.2012. Pola Penggunaan Pusat Layanan Internet Kecamatan (PLIK) untuk Pembangunan Sosioekonomi dan Perdesaan di Kab. Kulon Progo, DI. Yogyakarta. Balai Pengkajian dan Pengembangan Komunikasi dan Infomatika (BPPKI) Yogyakarta. Yogykarta.

Kementrian Riset Teknologi dan Pendidikan Tinggi Indonesia. 2017. Smartphone Rakyat Indonesia. https://www.dikti.go.id/ smartphone-rakyat-indonesia-2/. Diakses pada 3 Oktober 2017.

Laranti, A. 2017. Respons mahasiswa Fakultas Pertanian UGM terhadap website Agrotani. Skripsi S1. Universitas Gadjah Mada, Yogyakarta.

Magribi, M., 1999. Geografi Transportasi. Yogyakarta. Pasca Sarjana UGM.

Nazarudin Safaat Harahap. 2012. Pemograman Aplikasi Mobile Smartphone dan Tablet PC Berbasis Android. Informatika. Bandung.

Novia, R.A. 2011. Respons petani terhadap kegiatan Sekolah Lapangan Pengelolaan Tanaman Terpadu (SLPTT) di Kecamatan Ajibarang Kabupaten Banyumas. Mediagro 7 (2): $48-60$.

Pebriana, R. 2017. Peranan Teknologi Informasi berbasis Android terhadap Perkembangan Pertanian. https:// stipgrahakaryamuarabulian. ac.id/2017/04/22/peranan-teknologiinformasi-berbasis-android-terhadapperkembangan-pertanian/. Diakses pada 16 Januari 2018.
Rikardo, Yanuar. 2018. Peran Mahasiswa, Pemuda Sebagai Agent Of Change. https:// reportaserakyat.com/opini/peran-mahasiswapemuda-sebagai-agent-of-change/. Diakses pada tanggal 23 Agustus 2019.

Risnawati, E dan Irwandi, S. 2012. Analisis faktor atas pengambilan keputusan mahasiswa untuk memilih jurusan akuntansi di STIE Perbanas Surabaya. The Indonesian Accounting Review, Vol. 2 (1) : 63-72.

Septianita, W., Winarno, W., dan Arif, A. 2014. Pengaruh kualitas sistem, kualitas informasi, kualitas pelayanan Rail Ticketing System (RTS) terhadap kepuasan pengguna (studi empiris pada PT. KERETAAPIINDONESIA (PERSERO) DAOP 9 JEMBER). e-Jurnal Ekonomi dan Akuntansi, Vol. 1 (1) : 53-56.

Setijadi. 2005. Tekhnologi Informasi dalam Implementasi Proses Bisnis pada Supply Chain Management (SCM). Yogyakarta, Seminar Nasional Aplikasi Tekhnologi Informasi (SNATI 2005).

Siagian, Sondang. 1995. Teori Motivasi dan Aplikasinya. Jakarta. PT Rineka Cipta.

Suheni, E. 2011. Analisis nilai-nilai berita trending news „dokumen wikileaks menguliti duniae edisi 30 November - 4 Desember 2010 Harian Umum Republika. Skripsi S1. Universitas Islam Negeri Syarif Hidayatullah, Jakarta.

Sukadiyanto. 2004. Perbedaan reaksi emosional antara olahragawan body contact dan non body contact. Jurnal Psikologi, Vol. 33 (1): 50-62.

Suprayetno, A dan Brahmasari, I. 2008. Pengaruh motivasi kerja, kepemimpinan dan budaya organisasi terhadap kepuasan kerja karyawan serta dampaknya pada kinerja perusahaan (studi kasus pada PT. Pei Hai International Wiratama Indonesia). Jurnal Manajemen dan Kewirausahaan, Vol. 10 (2) :124-135.

Surhayat, Y. 2009. Hubungan antara sikap, minat, dan perilaku manusia. Jurnal Region, Vol. 1 (3) : 1-19. 
Suryadi, A. 2007. Pemanfaatan ICT dalam pembelajaran. Jurnal Pendidikan Terbuka dan Jarak Jauh, Vol. 8 (1) : 83-98.

Tim Penyusun Buku Panduan Akademik Program Sarjana Fakultas Pertanian UGM. 2013. Panduan Program Sarjana Fakultas Pertanian UGM Cetakan Tahun 2013. Fakultas Pertanain UGM, Yogyakarta.

Tim Penyusun Buku Panduan Akademik Program Sarjana Fakultas Pertanian UGM. 2018. Panduan Program Sarjana Fakultas Pertanian UGM Cetakan Tahun 2018. Fakultas Pertanain UGM, Yogyakarta.

Uno, Hamzah. 2013. Teori Motivasi dan Pengukurannya. Jakarta. Bumi Aksara.

Wiratama, Dwinanda. 2013. Pengaruh Kualitas Informasi, Persepsi Kebermanfaatan, Dan Computer Self Efficacy terhadap Penggunaan Internet Sebagai Sumber Pustaka. Jurnal Nominal. Universitas Negeri Yogyakarta.

Wirawan, S. 1995. Psikologi Lingkungan. PT Grasindo, Jakarta.

Zahra, Femilia (2009). Pengaruh Kualitas Informasi, Kemampuan Individual, dan Norma Subjektif terhadap Minat Mahasiswa dalam Menggunakan Internet sebagai Sumber Pustaka. Research Gate Journal.

Zakaria, Muhammad Iksan., Rokhman, M. Nur. 2018. Pengaruh Motivasi dan Penggunaan Internet terhadap Prestasi Belajar Siswa dalam Pembelajaran Sejarah di MAN 2 Yogyakarta Tahun Ajaran 2015/2016. Jurnal Nominal. Universitas Negeri Yogyakarta. 